\title{
Primary Intraosseous Squamous Cell Carcinoma
}

National Cancer Institute

\section{Source}

National Cancer Institute. Primary Intraosseous Squamous Cell Carcinoma. NCI

Thesaurus. Code C54295.

A squamous cell carcinoma that arises centrally from the jaw. It derives from

odontogenic epithelial remnants. It includes solid type squamous cell carcinoma,

squamous cell carcinoma that arises from an odontogenic cyst, and squamous cell carcinoma that derives from a keratocystic odontogenic tumor. 